\title{
Growth and reproductive performance of rabbit bucks fed replacement levels of fermented Jatropha (Jatropha carcass) seed meal \\ ${ }^{1}$ *Vandu, R. A., ${ }^{1}$ Mbaya, Y. P., ${ }^{2}$ Wafar, R. J. and ${ }^{2}$ Ndubuisi, D. I. \\ ${ }^{I}$ Department of Animal Science and Range Management, Modibbo Adama University of \\ Technology Yola, Adamawa State. \\ ${ }^{2}$ Department of Animal Production and Health, Federal University Wukari, Taraba State.
}

Abstract

*Corresponding author: rosemaryalbertvandu@gmail.com; 07036596287

\begin{abstract}
This study was conducted to investigate the effect of fermented Jatropha seed meal on growth and reproductive characteristics of rabbit bucks. Thirty (30) (twelve weeks old) cross bred rabbits (American chinchilla $\times$ New Zealand white) were used for the experiment. The rabbits were randomly assigned to five dietary treatments replicated three times with two rabbits per replicate in a completely randomised design (CRD). The five experimental diets were compounded using fermented Jatropha seed meal (FJSM) to replace soya bean meal at 0, 25, 50, 75 and 100\%, respectively. The experiment lasted for 12 weeks. Data collected during the feeding trial include final body weight, total weight gain, total feed intake, feed conversion ratio and mortality. At the end of the feeding trial, 3 bucks per treatment were slaughtered and the reproductive organs dissected out for testicular and epididymal morphometrics as well as gonadal sperm assessment. All the data collected during the experiment were subjected to analysis of variance. The result of the growth performance showed that final body weights and total weight gain were highly $(P<0.001)$ influenced by the replacement levels of fermented Jatropha seed meal. Final body weight of buck decreased as the level FJSM increased in the diets. Among the fermented Jatropha seed meal-based diets, rabbitfed T2 (25\% FJSM) recorded significant higher $(P<0.05)$ final body weight (2011.10g) than the other group. The results of epididymal and testicular characteristics as well as testicular sperm characteristics were significantly $(P<0.001)$ influenced by replacement levels of FJSM in the diets. It was concluded from this study that feeding rabbit buck with replacement levels of fermented Jatropha seed meal beyond 25\% adversely affected growth and reproductive performance. Therefore, it is recommended that fermented Jatropha seed meal at $25 \%$ replacement levels can be used in rabbit diets.
\end{abstract}

keywords: Buck, Fermentation, Growth, Jatropha, Rabbits, Reproductive Performance

\section{La Croissance et La performance reproductrice des mâles lapins nourris avec des niveaux de remplacement de farine de graines de jatropha fermenté (carcasse de Jatropha)}

\section{Résumé}

Cette étude a été menée pour étudier l'effet de la farine fermentée de graines de Jatropha sur la croissance et les caractéristiques reproductrices des mâles lapins. Trente (30) (douze semaines) lapins croisés (chinchilla américain $\times$ Nouvelle-Zélande) ont été utilisés pour l'expérience. Les lapins ont été assignés au hasard à cinq traitements diététiques répliqués trois fois avec deux lapins par réplique dans une conception complètement randomisée (le 'CRD'). Les cinq régimes expérimentaux ont été composés utilisant le repas fermenté de graine de Jatropha (le 'FJSM') pour remplacer le repas de haricot de soja à 0, 25, 50, 75 et $100 \%$, respectivement. L'expérience a duré 12 semaines. Les données recueillies au cours de 


\section{Growth and reproductive performance of rabbit bucks}

l'essai d'alimentation comprennent le poids corporel final, le gain de poids total, la consommation totale d'aliments pour animaux, le ratio de conversion des aliments pour animaux et la mortalité. À la fin de l'essai d'alimentation, 3 dollars par traitement ont été abattus et les organes reproducteurs disséqués pour l'évaluation testiculaire et épididymalmorphométrique ainsi que l'évaluation du sperme gonadal. Toutes les données recueillies au cours de l'expérience ont fait l'objet d'une analyse de la variance. Le résultat de la performance de croissance a prouvé que les poids corporels finaux et le gain total de poids ont été fortement $(P<0.001)$ influencés par les niveaux de remplacement $d u$ repas fermenté de graine de Jatropha. Le poids corporel final de buck a diminué pendant que le niveau FJSM augmentait dans les régimes. Parmi les régimes fermentés à base de farine de graines de Jatropha, le T2 nourri au lapin (25\% de 'FJSM') a enregistré un poids corporel final $(P<0,05)$ plus élevé $(2011,10$ g) que l'autre groupe. Les résultats des caractéristiques épididymales et testiculaires aussi bien que des caractéristiques testiculaires de sperme ont été sensiblement $(P<0.001)$ influencés par des niveaux de remplacement de FJSM dans les régimes. Il a été conclu de cette étude que l'alimentation de l'argent du lapin avec des niveaux de remplacement de farine fermentée de graines de Jatropha au-delà de 25\% a nui à la croissance et la performance reproductive. Par conséquent, il est recommandé que le repas fermenté de graine de Jatropha aux niveaux de remplacement de 25\% puisse être employé dans des régimes de lapin.

Mots-clés: mâles lapins, fermentation, Croissance, Jatropha, Performance reproductive

\section{Introduction}

The scarcity of conventional feedstuff most especially protein and energy sources in most developing countries of the world has continued to be one of the major challenges facing livestock producers (Biobaku and Dosunmu, 2003). Searching for alternative feedstuffs is paramount if animal production and supply of quality and quantity animal protein is to be sustained (Aro et al., 2009). Rabbit production has been identified as one of the fastest and most efficient means of attaining animal protein self-sufficiency (Yakubu and Wafar, 2014). This is attributed largely to the rabbit's high rate of reproduction, early maturity, rapid growth rate, efficient converter of feed to meat of high nutritional value (Ghosh et al. 2008). The production efficiency of commercial rabbit farms is largely dependent on the quality of semen the buck produces, litter size at kindling and the survivability of the bunnies up to weaning age (Odeyinka et al. 2008). In addition, the pre-weaning growth is very critical in meat rabbits due to its impact on the meat produced at the finisher stage of production (Gerencser et al., 2011). As production directly depends on reproduction, the reproductive performance of rabbits becomes an important aspect in determining the profitability of commercial rabbit breeding (Lazzaroni et al. 2012). However, nutrition and high cost of feed are among other factors affecting rabbit production. High cost of feed has been identified as an impending factor affecting successful rabbit production in most developing countries of the world (Apori et al., 2014). The search for alternative plant protein sources over the years as a replacement for conventional feedstuffs has been the focus of animal nutritionist, physiologist and breeders (Owen et al, 2010; Wafar and Tarimbuka, 2016). The use of non -conventional protein sources such as, pigeon pea (Ahamefule 2005), mucuna seed meal (Carew et al., 2003), cotton seed meal (Amao and Showunmi 2016), Kapok seed meal (Wafar et al.,2017) in animal ration is well documented. One of the nonconventional feedstuffs focused in this 


\section{Vandu, Mbaya, Wafar and Ndubuisi}

study is Jatropha carcass seed. Jatrophas are oil plants belonging to the Euphorbiaceae family. It has both toxic and non-toxic genotypes while Jatropha platyphylla is a non-toxic species (Makkar et al., 2012). It is known among some Nigerian ethnic groups as Bindazugu (Hausa), Kolkolaje, (Fulfulde), Lapalapa (Yoruba), Wuluidu (Igbo) and Safudruna (Higgi). They are drought-resistant perennial and multipurpose shrubs, similar to the cassava plant (Elbehri et al., 2013). The seed has been reported to contain $56.4 \%$ crude protein higher than that of full fat soya bean meal (48\%) (Makkar and Becker, 1999). This relatively high protein content of Jatropha curcas can be advantageous since it is not utilised by human beings as source of food (Hammarneh et al., 2012). However, Jatropha seed meal also contains antinutritional factors; such as lectin, trypsin inhibitor, saponin, phytate, and phorbolesters (Makkar and Becker, 1998, Antevy et al., 2017). Phorbol ester is considered as the most toxic anti-nutritional factor. The use of Jatropha in animal nutrition is however limited due to these anti-nutrients (Makkar and Becker, 1999). The use of processing methods such as cooking, toasting, fermentation and soaking have been reported to reduce the contents of anti-nutritional factor in Jatropha curcas seed meal (Antevy et al., 2017). A study conducted by Antevy et al. (2017) to evaluate the performance of broiler chickens fed differently processed Jatropha curcas seed meal showed that broiler chicken fed fermented Jatropha seed meal recorded higher feed intake, final body weight gain and superior feed conversion ratio. Fermentation is one of the oldest forms of feed processing and preservation Ross et al. (2002), and also has the capacity to improve nutritional and functional properties of the feed stuff such as improving the digestibility, flavor and reduce the levels of anti-nutrients in tropical seed meals thereby increasing the possibilities of its utilization. (Hotz and Gibson, 2007 and Frias et al. 2008) However, there is little or no information on the use of fermented Jatropha seed meal on the growth and reproductive parameter of rabbit buck. This study therefore was designed to assess the effects of fermented Jatropha seed meal on growth and reproductive performance of rabbit bucks.

\section{Materials and methods Location of the study}

This study was carried out at the Rabbit Unit of the Department of Animal Science and Range Management, Modibbo Adama University of Technology, Yola Adamawa State. Yola is between latitude $7^{\circ} 11^{\prime}$ North and Longitude $11^{\circ} 14^{\prime}$ East and at an elevation of $364 \mathrm{~m}$ above sea level in the north eastern part of Nigeria. It has mean relative humidity ranges from $30-50 \%$ with a minimum in February to March and as low as $10 \%$ and a maximum of about $90 \%$ in August. The maximum temperature can reach $38^{\circ} \mathrm{C}$ particularly in April, while minimum temperature can be as low as $18^{\circ} \mathrm{C}$ (Adebayo, 1999).

\section{Collection and processing of Jatropha curcas seeds}

Jatropha curcas fruits were purchased from Yola market. The fruits were cracked mechanically to remove the seeds and processed according to modified method of Wafar et al. (2019). Five kg of the seeds was packaged in a jute bag and placed in a pot containing 20 litres of water then cooked for 45 minutes. The use of jute bag is to control leaching and possibility of hydrolysis of some nitrate. The pot was placed on a tripod stand having firewood as a source of heat. The cooked seeds were packed in a polythene bag to allow natural fermentation to take place. The fermentation process lasted for 120 hours (5 days). The fermented Jatropha seeds were 


\section{Growth and reproductive performance of rabbit bucks}

sundried and milled using hammer milling machine to produce fermented Jatropha seed meal (FJSM).

Experimental animals, management, design and diets

Thirty buck rabbits (American chinchilla $\times$ New Zealand white) with an average weight of $(1140 \pm 2.0 \mathrm{~g})$ were procured within Yola metropolis. They were assigned to five dietary treatments. Replicated three times with two rabbits per replicate in a completely randomised design (CRD). Each rabbit was housed in a cage measuring $150 \mathrm{~cm} \times 100 \mathrm{~cm} \times 120 \mathrm{~cm}$ fitted with aluminium feeder and drinker. The experimental animals were given prophylactic treatment against endo and ecto-parasites using $0.3 \mathrm{ml} / \mathrm{kg}$ Ivomec ${ }^{\circledR}$.

Five diets were compounded using fermented Jatropha seed meal (FJSM) to replace soya bean meal at $0,25,50,75$ and $100 \%$ designated as treatment 1, 2, 3, 4 and 5 respectively as shown in Table 1 . The experiment lasted for 12 weeks.

\section{Laboratory analysis}

Proximate composition and anti-nutritional composition of raw and fermented Jatropha seed meal were determined (dry matter (DM), crude protein (CP), crude fibre (CF), ether extracts (EE) and Ash content) as described by AOAC (2010). The extraction of phorbolester was carried out using modified method of Makkar et al.(1997).

Table 1: Ingredient and percentage composition of the experimental diets

\begin{tabular}{llllll}
\hline \multirow{2}{*}{ Ingredients } & \multicolumn{5}{l}{ Replacement levels of fermented Jatropha seed meal } \\
\cline { 2 - 6 } M1 $(0 \%)$ & $\mathrm{T} 2(25 \%)$ & $\mathrm{T} 3(50 \%)$ & $\mathrm{T} 4(75 \%)$ & $\mathrm{T} 5(100 \%)$ \\
\hline SBM* & 52.00 & 52.00 & 52.00 & 52.00 & 52.00 \\
FJSM** & 18.00 & 13.50 & 9.00 & 4.50 & 0.00 \\
Groundnut haulms & 0.00 & 4.50 & 9.00 & 13.50 & 18.00 \\
Maize offal & 10.00 & 10.00 & 10.00 & 10.00 & 10.00 \\
Fish meal & 13.00 & 13.00 & 13.00 & 13.00 & 13.00 \\
Bone meal & 3.00 & 3.00 & 3.00 & 3.00 & 3.00 \\
Premix* & 3.00 & 3.00 & 3.00 & 3.00 & 3.00 \\
Lysine & 0.25 & 0.25 & 0.25 & 0.25 & 0.25 \\
Salt & 0.25 & 0.25 & 0.25 & 0.25 & 0.25 \\
Methionine & 0.25 & 0.25 & 0.25 & 0.25 & 0.25 \\
Total & 0.25 & 0.25 & 0.25 & 0.25 & 0.25 \\
Calculated analysis & 100 & 100 & 100 & 100 & 100 \\
Crude protein & & & & & \\
Crude fibre & 16.83 & 16.64 & 16.73 & 16.65 & 16.70 \\
Ca & 8.84 & 8.76 & 8.70 & 8.63 & 8.69 \\
P & 1.23 & 1.22 & 1.20 & 1.23 & 1.24 \\
Lysine & 0.90 & 0.90 & 0.91 & 0.89 & 0.83 \\
Methionine & 0.91 & 1.89 & 0.88 & 0.97 & 0.89 \\
$* * *$ ME Kcal/kg & 0.58 & 0.63 & 0.61 & 0.59 & 0.60 \\
\hline Vitamin-ming & 2978.14 & 2998.13 & 2990.14 & 2992.88 & 2991.34 \\
\hline
\end{tabular}

*Vitamin-mineral premix provided the following per kg of feed: Vit. A 1500 IU; Vit.D 3000 IU; Vit.E 30 IU; Vit.K 2.5mg; Thiamine B 1 3mg; Riboflavin B 6 mg; Pyrodoxine B 6 mg; Niacin 40 mg; Vit. B 120.0 mg; Pantothenic acid 10mg; Folic acid 1mg; Biotin $0.08 \mathrm{mg}$; Chloride 0.125mg; Mn 0.0956 g; Antioxidant 0.125 g; Fe 0.024 g; Cu 0.006 g; Se 0.24 g; Co 0.24.

$\mathrm{SBM}^{*=}$ Soya bean meal, FJSM**=Fermented Jatropha seed meal, ME**= Metabolizable energy

\section{Data collection}

\section{Growth parameter}

The growth parameter determined were feed intake, weight gain and FCR was calculated as ratio of total feed intake to total weight gain. Feed intake was calculated as the difference between feed offered and left over after a period of 24hours 


\section{Evaluation of reproductive parameter}

At the end of 12 weeks of feeding trial, 3 bucks per treatment were randomly selected and slaughtered for reproductive organs evaluation.

\section{Testicular morphometry}

After slaughtering, the epididymis was trimmed off the testis; the right and left testis were weighed using a digital scale (MLP 231 scale). The length and width of testis were measured using a pair of vernier caliper while the volume of the testis was determined using water displacement method of Archimede's principle using a measuring cylinder.

The testicular morphometry parameter evaluated were:

Paired testis weight (g), left testis weight $(\mathrm{g})$, right testis weight $(\mathrm{g})$, mean testis length $(\mathrm{cm})$

Left testis length $(\mathrm{cm})$, right testis length $(\mathrm{cm})$, left testis width $(\mathrm{cm})$, right testis width $(\mathrm{cm})$. Paired testis volume $(\mathrm{ml})$, left testis volume ( $\mathrm{ml})$, right testis volume ( $\mathrm{ml})$.

\section{Epididymal morphometry}

Epididymal parameters include: left epididymal weight (g), right epididymal weight ( $\mathrm{g}$ ), left epididymal length $(\mathrm{cm})$, right epididymal length $(\mathrm{cm})$

\section{Sperm analysis}

Sperm morphology was determined according to the method described by Zemjanis (1970). A smear of the semen was made by cutting the right testis along the equatorial region and rubbing the cut surface on a clean glass slide. Two drops of eosin-nigrosin dye that had been thoroughly mixed was added. Another smear was made on a glass slide and viewed under a light microscope to identify normal and abnormal cells on the slide. The normal cells were expressed as the percentage of number of cells counted on each field of the slide (Ogbuewu, 2008). Sperm count was determined haemocytometrically by homogenization technique as described by Adejumo (2006) and Amao et al. (2012).
The tunica albuginea was carefully removed from the testis. A portion of the parenchyma tissue was taken and homogenized by maceration with a pair of sharp scissors for 5 minutes in a beaker containing $10 \mathrm{ml}$ of physiological saline solution. The homogenate was filtered through a double layer cheese cloth and the filtrate diluted to ratio 1:20 with de-ionized water. Some drops of the homogenate were introduced into an improved Neubauer haemocytometer counting chamber. All the elongated spermatids and mature sperm cells in the four diagonal and the centre squares of the haemocytometer were counted in each diluted homogenate.

Motility was determined by a modification of the method of Ogbuewu et al. (2008). A drop of the homogenate was placed on a sterile slide, covered with a cover slip and observed under the microscope at X 400 Magnification and scored between 0 and $100 \%$.

The parameters evaluated were sperm count, motile and non- motile sperm percentages, sperm volume and concentration, normal and abnormal sperm, round and elongated spermatids.

\section{Statistical analysis}

All data obtained were subjected to analysis of variance (ANOVA) using JMP SAS (2013) software where significant differences exited, Duncan's Multiple Range Test (DMRT) option of same software were used to separate means.

\section{Results and discussion \\ Proximate and antinutritional composition of raw and fermented Jatropha Seed meal}

The proximate and anti-nutritional compositions of the raw and fermented Jatropha seed meal (FJSM) are presented in Table 2. The results showed FJSM recorded higher values of crude Protein (CP) $43.67 \%$, ash $(9.13 \%)$ and lower values of crude fibre $(2.41 \%)$, ether extracts 


\section{Growth and reproductive performance of rabbit bucks}

(20.18\%), nitrogen free extracts (NFE) $(14.52 \%)$ and metabolizable energy (3765.83\%), respectively. The crude fibre (CF) and ether extracts (EE) values ranged from $10.30-14.32 \%$ and $2.17-4.76 \%$, /respectively. Nitrogen free extract for raw and fermented jatropha meals were 48.61 and $48.14 \%$ respectively. The result of the anti-nutritional factors (ANFs) composition however, shows that raw Jatropha seed contained $3.32 \mathrm{mg} / 100 \mathrm{~g}$ phorbolester, $20.45 \mathrm{mg} / 100 \mathrm{~g}$ trypsin inhibitors, $191.56 \mathrm{mg} / 100 \mathrm{~g}$ saponnin, $278.67 \mathrm{mg} / 100 \mathrm{~g}$ tannin, $94.67 \mathrm{mg} / 100 \mathrm{~g}$ oxalates and $234.56 \mathrm{mg} / 100 \mathrm{~g}$ phytates, while the fermented Jatropha seed recorded $2.11 \mathrm{mg}$ phorbolester, $8.67 \mathrm{mg} / 100 \mathrm{~g}$ trypsin inhibitors, $78.96 \mathrm{mg} / 100 \mathrm{~g}$ saponnin, $87.89 \mathrm{mg} / 100 \mathrm{~g}$ tannins $56.45 \mathrm{mg} / 100 \mathrm{~g}$ oxalates and $58.11 \mathrm{mg} / 100 \mathrm{~g}$ phytates. The results showed decrease in antinutrients as a result of fermentation. The higher crude protein $(\mathrm{CP})$ content observed in fermented Jatropha seed meal could be attributed to the effect of the fermentation process that leads to crude protein improvement. The $\mathrm{CP}$ values of both raw and fermented Jatropha seed meal were within the range of $35-50 \%$ crude protein reported by Aslani et al. (2007). This indicates that fermented Jatropha seed meal may be comparable to soybean meal in its usefulness in rabbit diets (Makkar et al., 1998). Presences of anti-nutrients in the raw jatropha seed meal confirm the earlier report of Makkar and Becker, (1999) that jatropha seed meal contained high concentration of antinutritional factors (ANFs). The use of fermentation as a method of detoxification however, reduced the concentration of ANFs and increased the nutrient composition of Jatropha seed meal, but did not completely remove the ANFs in the seed. The finding is in line with earlier reports of Makkar et al. (1998), Wafar (2013) and Yakubu et al. (2017) when they subjected tropical legume seeds to different processing methods and recorded partial reduction of ANFs in the seeds.

Table 2: Proximate composition of raw and fermented Jatropha seed meal

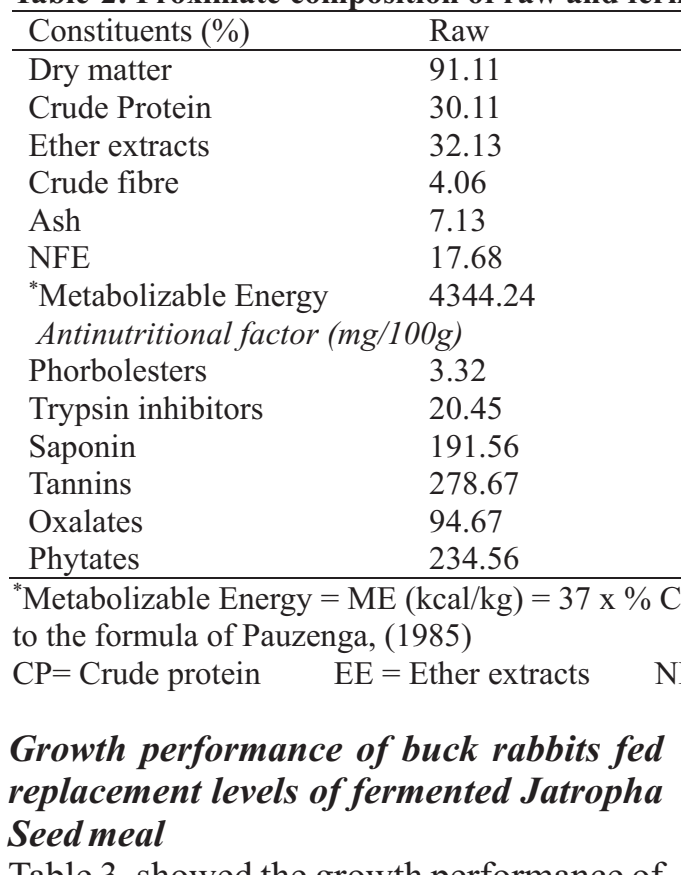

Fermented

89.91

43.67

20.18

2.41

9.13

14.52

3765.83

$\%$ Reduction

$2.11 \quad 63.55$

$8.67 \quad 42.39$

$\begin{array}{ll}78.98 & 41.22\end{array}$

$\begin{array}{ll}87.89 & 31.53\end{array}$

$56.45 \quad 59.62$

$58.11 \quad 24.77$

${ }^{*}$ Metabolizable Energy $=$ ME $(\mathrm{kcal} / \mathrm{kg})=37 \mathrm{x} \% \mathrm{CP}+81 \mathrm{x} \% \mathrm{EE}+35.5 \mathrm{x} \%$ NFE. Calculated according to the formula of Pauzenga, (1985)

$\mathrm{CP}=$ Crude protein $\quad \mathrm{EE}=$ Ether extracts $\quad \mathrm{NFE}=$ Nitrogen free extracts

Growth performance of buck rabbits fed Seed meal

Table 3, showed the growth performance of buck rabbits fed replacement levels fermented Jatropha seed meal. The final body weights and total weight gain were highly $(\mathrm{P}<0.001)$ influenced by the 
replacement levels of fermented Jatropha seed meal. Final body weight of buck decreased as the level FJSM increased in the diets. Among the fermented Jatropha seed meal based diets rabbit fed T2 $(25 \%$ FJSM) recorded significantly higher $(\mathrm{P}<0.05)$ final body weight 2011.10g. Total body weight gain and total feed intake varied from $217.07 \mathrm{~g}$ in T5 (100\% FJSM) to $1330.55 \mathrm{~g}$ in T1 (0\% FJSM) and $1206.51 \mathrm{~g}$ in $\mathrm{T} 1 \quad(25 \%$ FJSM) to $4325.70 \mathrm{~g}$ in $\mathrm{T} 1$ $(0 \%$ FJSM) respectively. Feed conversion ratio also differed significantly $(\mathrm{P}<0.05)$ across the treatments. It was observed that the superior feed conversion was recorded T1 (0\%FJSM) 3.25 while those fed T5 (100\%FJSM) recorded poor feed conversion ratio. Rabbit fed $\mathrm{T} 5$ had higher mortality (3.00\%). It was observed from the study that rabbits' bucks fed T3 (50\% FJSM), T4 (75\% FJMS) and T5 (100\% FJSM) recorded lower feed intake. The low feed intake could be attributed to the residual effect of anti-nutritional factors in the fermented Jatropha seed meal which resulted to low palatability of diets. Tannins and saponins have reported to decrease feed intake as a result of its astringent properties (Ogbu et al. (2015). Weaver and Kanna,
(2002) in their study also reported that phytate reduce the bioavailability of divalent cations due to insoluble complexes formation during digestion and absorption of minerals. This implied that rabbit buck fed diets containing 50, 75 and 100\% FJSM replacement levels could not efficiently absorb the dietary nutrients available in the gastro-intestinal tract as a result of high concentration of these residual antinutritional factors. Esonu et al. (2001) reported that high trypsin inhibitors in the diet reduce protein digestibility resulting in poor utilization of available nutrients. Phorbol esters are toxic to livestock even at very low concentrations (Goel et al., 2007). The result from this study confirmed earlier findings of Abdel-Shafy et al. (2011) who reported significant reduction in feed intake and growth rate of more than $30 \%$ as a result of residual phorbol esters in Jatropha seed meal. Rabbit fed T5 (100\% FJSM) recorded high percentage mortality this could be attributed to residual content of phorbolester. Agboola and Adenuga, (2015) reported high percentage of mortality of birds fed $10 \%$ inclusion level of Jatropha seed meal

Table 3: Growth Performance of Buck rabbits FedReplacement levels of Fermented Jatropha Seed meal

\begin{tabular}{llllllll}
\hline & \multicolumn{7}{c}{ Replacement levels of fermented Jatropha seed meal } \\
\cline { 2 - 7 } Parameter & T1 $(0 \%)$ & T2 $(25 \%)$ & T3 $(50 \%)$ & T4 $(75 \%)$ & T5 $(100 \%)$ & SEM & P-value \\
\hline Initial body weight $(\mathrm{g})$ & 1225.29 & 1195.34 & 1205.53 & 1140.47 & 1188.41 & 21.73 & 0.12 \\
Final body weight $(\mathrm{g})$ & $2555.83^{\mathrm{a}}$ & $2011.10^{\mathrm{b}}$ & $1554.85^{\mathrm{c}}$ & $1623.57^{\mathrm{c}}$ & $1405.48^{\mathrm{d}}$ & 34.34 & 0.01 \\
Total weight gain $(\mathrm{g})$ & $1330.55^{\mathrm{a}}$ & $815.76^{\mathrm{b}}$ & $344.32^{\mathrm{cd}}$ & $484.11^{\mathrm{c}}$ & $217.07^{\mathrm{d}}$ & 30.86 & 0.02 \\
Total feed intake $(\mathrm{g})$ & $4325.70^{\mathrm{a}}$ & $3599.06^{\mathrm{b}}$ & $1531.02^{\mathrm{d}}$ & $2565.67^{\mathrm{c}}$ & $1206.51^{\mathrm{e}}$ & 47.00 & 0.01 \\
Feed conversion ratio & $3.25^{\mathrm{b}}$ & $4.41^{\mathrm{ab}}$ & $4.57^{\mathrm{ab}}$ & $5.30^{\mathrm{ab}}$ & $5.58^{\mathrm{a}}$ & 0.38 & 0.04 \\
Mortality (\%) & 0 & 1.00 & 1.00 & 1.00 & 3.00 & - & - \\
\hline
\end{tabular}

Means in the same row bearing different superscripts differ significantly

$\mathrm{SEM}=$ Standard error mean, $\mathrm{ns}=$ not significant

Testicular characteristics of rabbit bucks fed fermented levels of fermented seed meal

The result showed significant variations by the levels replacement (Table 4). The values recorded for the right testis and left testis weights were within the range of $1.00-$ $1.80 \mathrm{~g}, 1.05 \mathrm{~g}-1.84 \mathrm{~g}$ and $2.05-3.64 \mathrm{~g}$ respectively. Bucks fed Jatropha based diets especially beyond $25 \%$ inclusion had significant lower weight testis weighs. From the result it appeared the inclusion of 


\section{Growth and reproductive performance of rabbit bucks}

fermented Jatropha seed meal in the diet relatively decreased the weight of the testis. The ability of the testes to store spermatozoa is of immense importance in rabbit breeding programme. The decrease in testicular sperm reserve observed on rabbit fed T3 (50\%), T4 (75\%) and T5 $(100 \%)$ fermented Jatropha seed meal is a pointer that higher inclusion of the seed meal negatively affected testicular sperm reserve. This indicates that feeding fermented Jatropha seed meal in rabbit diet beyond $25 \%$ is detrimental to the development of spermatogenic potentials of the buck as it has been observed in this present study. Testis size is a good indicator of the present and future spermatozoa production of an animal (Perry and
Petterson, 2001; Gupta and Mohanty, 2003; Togun and Egbunike, 2006). The knowledge of basic morphometric characteristics of the reproductive organs have been found to provide valuable information in the evaluation of breeding and fertility potential of the animals (Galmessa et al., 2003). Larger testes (without any abnormality) have been reported to produce more spermatozoa than smaller testes (Oyeyemi et al., 2002;). Morton (2006) reported that in sacrificed animals, decreased weight of the testes indicates widespread or diffuse loss of seminiferous epithelial cells. The testes which possess greater number of sertoli cells were heavier and produced more spermatozoa than testes with fewer sertoli cells (Britto et al., 2004).

Table 4: Testicular characteristics of rabbit buck fed replacement levels of fermented seed meal

\begin{tabular}{|c|c|c|c|c|c|c|c|}
\hline \multirow[b]{2}{*}{ Parameter } & \multicolumn{5}{|c|}{ Replacement levels of fermented Jatropha seed meal } & \multirow[b]{2}{*}{ SEM } & \multirow[b]{2}{*}{ P-value } \\
\hline & $\mathrm{T} 1(0 \%)$ & $\mathrm{T} 2(25 \%)$ & $\mathrm{T} 3(50 \%)$ & $\mathrm{T} 4(75 \%)$ & T5 $(100 \%)$ & & \\
\hline Right testis weight $(\mathrm{g})$ & $1.80^{\mathrm{a}}$ & $1.51^{\mathrm{b}}$ & $1.04^{\mathrm{b}}$ & $1.03^{\mathrm{c}}$ & $1.00^{\mathrm{d}}$ & 0.38 & 0.05 \\
\hline Left testis weight $(\mathrm{g})$ & $1.84 \mathrm{a}$ & $1.43^{\mathrm{b}}$ & $1.30^{\mathrm{b}}$ & $1.50^{\mathrm{b}}$ & $1.05^{\mathrm{b}}$ & 0.37 & 0.03 \\
\hline Paired testis weight $(\mathrm{g})$ & $3.64^{\mathrm{a}}$ & $2.94^{\mathrm{b}}$ & $2.34^{\mathrm{c}}$ & $2.53^{\mathrm{c}}$ & $2.05^{\mathrm{c}}$ & 0.38 & 0.04 \\
\hline Left testis length $(\mathrm{cm})$ & $2.45^{\mathrm{a}}$ & $2.16^{\mathrm{b}}$ & $1.23^{\mathrm{c}}$ & $1.15^{\mathrm{c}}$ & $1.03^{\mathrm{c}}$ & 0.92 & 0.05 \\
\hline Right testis length $(\mathrm{cm})$ & $2.40^{\mathrm{a}}$ & $2.01^{\mathrm{a}}$ & $1.13^{\mathrm{b}}$ & $1.02^{\mathrm{b}}$ & $1.02^{\mathrm{b}}$ & 0.44 & 0.03 \\
\hline Mean testis length $(\mathrm{cm})$ & $2.43^{\mathrm{a}}$ & $2.08^{\mathrm{b}}$ & $1.18^{\mathrm{c}}$ & $1.08^{\mathrm{c}}$ & $1.02^{\mathrm{c}}$ & 0.71 & 0.05 \\
\hline Left testis width $(\mathrm{cm})$ & $1.93^{\mathrm{a}}$ & $1.79^{\mathrm{a}}$ & $1.13^{\mathrm{b}}$ & $1.09^{\mathrm{b}}$ & $1.02^{\mathrm{c}}$ & 0.30 & 0.04 \\
\hline Right testis width $(\mathrm{cm})$ & $1.79^{\mathrm{a}}$ & $1.68^{\mathrm{b}}$ & $1.09^{\mathrm{c}}$ & $1.07^{\mathrm{c}}$ & $1.05^{\mathrm{c}}$ & 0.29 & 0.02 \\
\hline Mean testis width (cm) & $1.86^{\mathrm{a}}$ & $1.74^{\mathrm{b}}$ & $1.11^{\mathrm{c}}$ & $1.08^{\mathrm{c}}$ & $1.03^{\mathrm{c}}$ & 0.49 & 0.05 \\
\hline Right testis volume (ml) & $3.19^{\mathrm{a}}$ & $3.15^{\mathrm{a}}$ & $2.87^{\mathrm{b}}$ & $2.79^{\mathrm{b}}$ & $2.18^{\mathrm{b}}$ & 0.65 & 0.04 \\
\hline Left testis volume (ml) & $3.30^{\mathrm{a}}$ & $3.40^{\mathrm{a}}$ & $2.74^{\mathrm{b}}$ & $2.80^{\mathrm{b}}$ & $2.82^{\mathrm{b}}$ & 0.64 & 0.03 \\
\hline Paired testis volume(ml) & $3.25^{\mathrm{a}}$ & $3.28^{\mathrm{a}}$ & $2.80^{\mathrm{b}}$ & $2.79^{b}$ & $2.50^{\mathrm{b}}$ & 1.48 & 0.02 \\
\hline
\end{tabular}

Means in the same row bearing different superscripts differ significantly

$\mathrm{SEM}=$ Standard error mean

Epididymal characteristics of rabbit bucks fed graded levels of fermented seed meal

Table 5, shows the epididymal characteristics of rabbit bucks fed graded levels of fermented seed meal. The result revealed all the parameters evaluated were significantly influenced. Mean epididymis weight and mean epididymis length were significantly affected by replacement levels of fermented Jatropha carcass seed meal in the diets. The mean epididymis weight of the bucks on the T1 ( $0 \%$ FJSM) $2.73 \mathrm{~g}$ and
T2 (25\% FJSM) $2.74 \mathrm{~g}$ were significantly $(\mathrm{p}<0.05)$ heavier compare to those on T3 (50\% FJSM) 1.79 g, T4 (75\% FJSM) $1.74 \mathrm{~g}$ and T5 (100\% FJSM) $1.60 \mathrm{~g}$. The right and left and epididymis weights of rabbit bucks fed replacement levels of fermented Jatropha seed meal are within the range of $1.74-2.74 \mathrm{~g}, 1.46-2.75 \mathrm{~g}$ and $1.60-2.73 \mathrm{~g}$ respectively. The higher epididymis weight of rabbits on T1 ( $0.0 \%$ FJSM) and T2 (25\% FJSM) implies that the bucks have the ability to store spermatozoa. Smaller 


\section{Vandu, Mbaya, Wafar and Ndubuisi}

epididymis weights of the bucks on T3 (50\%), T4 (75\% FJSM) and T5 (100\% FJSM) inclusion levels of fermented Jatropha seed meal suggest fewer spermatozoa is being stored (Perry and Petterson, 2001). The higher epididymis weight of observed in rabbits fed T1 $(0 \%$ FJSM) and T2 (25\% FJSM) were within the normal weight of epididymis (2- 3.0g) reported by Olomu et al., (2019) for buck rabbits raised under tropical condition. This implies that fermented Jatropha seed meal promotes the growth and development of testicular glands and gonadal sperm reserve. Colenbrander and Kemp (1990) reported that testicular weight and quantity of sperm produced are correlated. Morris et al. (1999) also stated that within a species of animals, there often exist positive correlation between spermatozoa production, testicular size and testicular length.

Table 5: Epididymal characteristics of rabbit buck fed Replacement levels of fermented seed meal

\begin{tabular}{llllllll}
\hline & \multicolumn{7}{l}{ Replacement levels of fermented Jatropha seed meal } \\
\cline { 2 - 7 } Parameter & $\mathrm{T} 1(0 \%)$ & $\mathrm{T} 2(25 \%)$ & $\mathrm{T} 3(50 \%)$ & $\mathrm{T} 4(75 \%)$ & $\mathrm{T} 5(100 \%)$ & SEM & P-value \\
\hline Left epididymal weight $(\mathrm{g})$ & $2.75^{\mathrm{a}}$ & $2.73^{\mathrm{a}}$ & $1.85^{\mathrm{b}}$ & $1.74^{\mathrm{b}}$ & $1.46^{\mathrm{c}}$ & 0.68 & 0.04 \\
Right epididymal weight $(\mathrm{g})$ & $2.70^{\mathrm{a}}$ & $2.74^{\mathrm{a}}$ & $1.73^{\mathrm{b}}$ & $1.75^{\mathrm{b}}$ & $1.74^{\mathrm{b}}$ & 0.64 & 0.02 \\
Mean epididymal weight $(\mathrm{g})$ & $2.73^{\mathrm{a}}$ & $2.74^{\mathrm{a}}$ & $1.79^{\mathrm{b}}$ & $1.74^{\mathrm{b}}$ & $1.60^{\mathrm{b}}$ & 1.09 & 0.05 \\
Left epididymal length $(\mathrm{cm})$ & $17.35^{\mathrm{a}}$ & $16.30^{\mathrm{b}}$ & $14.29^{\mathrm{c}}$ & $13.31^{\mathrm{d}}$ & $11.27^{\mathrm{e}}$ & 0.69 & 0.03 \\
Right epididymal length $(\mathrm{cm})$ & $17.05^{\mathrm{a}}$ & $15.89^{\mathrm{a}}$ & $14.10^{\mathrm{b}}$ & $13.29^{\mathrm{c}}$ & $11.18^{\mathrm{d}}$ & 0.61 & 0.02 \\
Mean epididymal length $(\mathrm{cm})$ & $17.20^{\mathrm{a}}$ & $16.09^{\mathrm{a}}$ & $14.19^{\mathrm{b}}$ & $13.30^{\mathrm{b}}$ & $11.22^{\mathrm{c}}$ & 1.10 & 0.02 \\
\hline
\end{tabular}

Means in the same row bearing different superscripts differ significantly $\mathrm{SEM}=$ Standard error mean

Testicular sperm characteristics of rabbit buck fed replacement fermented levels of Jatropha seed meal

The results of testicular sperm characteristics are presented in Table 6 . The result showed significant variation $(\mathrm{P}<0.001)$ across the dietary treatments. Rabbit T1 (0\% FJSM) $183.12 \times 10^{6}$ recorded significant higher $(\mathrm{P}<0.001)$ sperm cell count but similar to those on $\mathrm{T} 2$ (25\% FJSM) $170.67 \times 10^{6}$ compare to those fed T3 (50\% FJSM), T4 (75\% FJSM) and T5 (100\% FJSM) diets. The values for motile and non-motile sperm were between 30.12 in T5 $(100 \%)-76.22 \%$ in T $1(0.00 \%)$ and 10.45 in $\mathrm{T} 1(0 \%)$ to $57.67 \%$ in $\mathrm{T} 5$ (100\%). Buck fed T1 (0\%) fermented Jatropha seed meal recorded the least non motile value of $10.45 \%$. The result showed that motile sperm decrease progressively as the level of fermented Jatropha seed meal increased in the diet, while abnormal sperm percentages increase progressively with increase in levels of fermented Jatropha seed meal. One of the methods of assessing reproductive efficiency of the buck rabbit is through the measurement of semen quality (Ogbuewu et al., 2008). Every animal species has its capacity for sperm production, which is determined genetically but it has however, been clearly observed that other factors like nutrition, disease and stress influence the portion of the germinal epithelium that enters into spermatogenesis (Harper et al., 1999). The results of this study clearly indicate that dietary inclusion of fermented Jatropha seed meal beyond $25 \%$ negatively affect the testicular sperm characteristics of buck rabbits. Nutrition has long ago been established in affecting the secretory functions of the accessory sex glands, the products of which constitute the seminal plasma (Oyeyemi and Okediran, 2007). The progressive decrease of sperm cell count on rabbit fed graded levels of fermented Jatropha seed meal agreed with the findings of Ogbuewu et al. (2008) that secretory functions of the accessory sex glands are very sensitive to dietary changes and that 
the slight changes in feed chemical composition goes a long way in influencing sperm quantity. Sperm motility is an important index in reproductive assessment because it demonstrates the ability of sperm to move and fertilize an ovum (Ogbuewu, 2008). Significant higher number of motile sperm cells in buck rabbits fed T1 $(0.0 \%$ FJSM) and T2 (25\% FJSM) could be attributed to sperm cell development in the seminiferous tubules, in the sense that spermatozoa may need a moderate but progressive development for them to have excellent motility.

Table 6: Testicular sperm characteristics of buck rabbit buck fed replacement levels of fermented Jatropha seed meal

\begin{tabular}{llllllll}
\hline & \multicolumn{7}{l}{ Replacement levels of fermented Jatropha seed meal } \\
\cline { 2 - 7 } Parameters & T1 $(0 \%)$ & T2 $(25 \%)$ & T3 $(50 \%)$ & T4 $(75 \%)$ & T5 $\left(100^{\mathrm{o}}\right)$ & SEM & P-value \\
\hline Sperm count $\left(\mathrm{x} 10^{6}\right)$ & $183.12^{\mathrm{a}}$ & $170.67^{\mathrm{ab}}$ & $130.11^{\mathrm{b}}$ & $120.00^{\mathrm{c}}$ & $100.67^{\mathrm{d}}$ & 5.78 & 0.02 \\
Motile sperm $(\%)$ & $76.22^{\mathrm{a}}$ & $61.67^{\mathrm{b}}$ & $40.11^{\mathrm{c}}$ & $35.23^{\mathrm{c}}$ & $30.12 \mathrm{c}$ & 1.01 & 0.04 \\
Non motile sperm (\%) & $10.45^{\mathrm{d}}$ & $20.45^{\mathrm{c}}$ & $30.13^{\mathrm{b}}$ & $56.45^{\mathrm{a}}$ & $57.67^{\mathrm{a}}$ & 2.52 & 0.01 \\
Normal sperm (\%) & $70.11^{\mathrm{a}}$ & $64.23^{\mathrm{b}}$ & $20.34^{\mathrm{c}}$ & $20.11^{\mathrm{c}}$ & $18.67^{\mathrm{c}}$ & 1.20 & 0.03 \\
Abnormal sperm (\%) & $10.56^{\mathrm{c}}$ & $21.56^{\mathrm{c}}$ & $32.54^{\mathrm{b}}$ & $34.11^{\mathrm{b}}$ & $40.11^{\mathrm{a}}$ & 4.81 & 0.03 \\
\hline
\end{tabular}

Means in the same row bearing different superscripts differ significantly

$\mathrm{SEM}=$ Standard error mean

\section{Conclusion and recommendation}

It was concluded from this study that feeding rabbit buck with replacement of fermented Jatropha seed meal beyond 25\% adversely affected growth and reproductive performance. Therefore, it is recommended that fermented Jatropha seed meal at 25\% replacement levels can be used in rabbit diets.

\section{References}

Abdel-Shafy, S., Nasr, S. M., AbdelRahman, H. H. and Habeeb, S. M. 2011. Effect of Various Levels of Dietary Jatropha curcas seed Meal on Rabbits Infested by the Adult Ticks of Hyalomma Marginatum Marginatun in Animal Performance, Anti-tick feeding and Haemogram. Tropical Animal Health Production, 43 (2): 347-357.

Adebayo, A. A. 1999. Climate II. In: Adamawa State in Maps. Edit; (A. A. Adebayo and A. L. Tukur). Paracleate publishers, Yola, Nigeria Pp 58

Adejumo, D. O. 2006. Effect of supplemental cocoa husk on testicular characteristics of pigs.Nigerian Journal of Animal Production; 33(1): 151-156

Agboola, A. F. and Adenuga, A. A. 2015. Performance and organ histopathology of growing Japanese quails (Coturnix coturnix japonica) fed heat treated Jatropha seed cake substituted for soyabean meal. Tropical Animal Production Investigation 18: 1-8

Ahamefule, F. O. 2005. Evaluation of Pigeon Pea-Cassava Peel Based Diets for Goats Production in South-Eastern Nigeria Ph.D. Thesis College of Animal Science and Animal Production, MOUAU, Umudike, Nigeria

Amao, O. A. and Showunmi, K. A. 2016. Reproductive Characteristics of Rabbit Bucks Fed Diet Containing Raw or Fermented Cottonseed Cake. British Biotechnology Journal 10(3): 1-7

Amao, O. A., Togun, V.A. and Adejumo, D.O. 2012. Gonadal and extragonadal sperm characteristics of rabbit bucks fed cottonseed cakebased diets supplemented with 
Vitamin E. Journal of Animal Science Advances2(10):793-802

Antyev, M., Yakubu, B., Aliyara, Y.H., and Wafar, R. J. 2017. Effects of Processing Methods of Jatrophacurcas Seed Meal on Growth Performance and Blood Profile of Broiler Finisher Chickens.Asian Research Journal of Agriculture. 4 (4): 1-9

AOAC 2010. Official Method of Analysis, $14^{\text {th }}$ edition of the Official Analytical Chemist Standard Method Arlingo, U.S.A.

Apori, S. O., Hagan, J. K. and Osei, I. D. 2014. The rowth and reproductive performance of different breeds of rabbits kept under warm and humid e $\mathrm{n} v \mathrm{i}$ o $\mathrm{nm}$ e $\mathrm{n} \mathrm{t} \mathrm{s}$ i $\mathrm{n}$ Ghana.OnlineJournal of Animal and Feed Research 4(3): 51-59

Aslani, M. R., Maleki, M., Mohri, M., Sharifi, K., Najjar- Nezhad, V. and Afshari, E. 2007. Castor bean (Ricinus communis) toxicosis in a sheep flock. Toxicology 49: 400406

Aro, S. O., Adejumo, D. O., Aletor, V. A., Adebayo, A. A., Ashimi, A. A., Adejaji, O. J. and Adesida, J. A. 2009. Growth responses and faecal evaluation of weaning pigs fed Biotechnologically Enhanced Cassava tuber waste (CTW) diets. Proceedings of the 14th Annual conference of Animal Science Association of Nigeria ASAN September $14^{\text {th }}-17^{\text {th }} 2009$ LAUTECH Ogmoso Nigeria.

Belewu, M. A. 2008. Replacement of Fungus Treated Jatropha curcas Kernel Meal in the Diet of Rat. Green Farming.2 (3): 154 - 157.

Biobaku, W. O. and Dosunmu, E. O. 2003. Growth response of rabbits fed graded level of processed and un-dehulled sunflower seed.
Nigerian Journal of Animal Production. 30(2): 179-184.

Britto, I. F. C., Silva, A. E. D. F., Unainian, M. M., Dode, M. A. N., Barbos, R. T. and Kastelic, J. P. 2004. Sexual development in early and late maturing Bos indicus and Bos indicus $\times$ Bos Taurus crossbred bulls in Brazil. Theriogenology, Elsevier Science Inc. New York, USA. 62:1177-2177

Carew, L. B., Hardy, D., Weis, J., Alsters, F., Mischler, S. A., Gernat, A. and Zakrzewska, F. I. 2003. Heating raw velvet beans (Mucuna pruriens) reverses $\mathrm{s}$ o $\mathrm{m} \mathrm{e}$ anti-nutritional effects on organ growth, blood chemistry, and organ histology in growing chickens. Tropical and Subtropical Agroecosystems 1: 267-275

Colenbrander, B. and Kemp, B. 1990. Factors influencing semen quality in pigs. Journal of Reproduction \& Fertility 40:105-115

Elbehri, A., Segerstedt, A. and Liu, P. 2013. A global assessment of sustainability biofuels and sustainability challenges, issues, trends and policies for biofuels and related feedstock's. FAO, Rome, Italy.

Esonu, B. O., Undedibie, A. B. I., Herbert, U., Odey, J. O. and Odu, S. 2011. Comparative Evaluation of Raw and Cooked jack been (Canavalia insiformis) on the performance of weaner rabbits. World Rabbit Science 4:139-141

Frias, J., Song, Y. S., MartinezVillaluenga, C., De Mejia, E. G. and Vidal-Valverde, C. 2008. Immunoreactivity and amino acid content of fermented soya bean products. Journal of Agriculture and Food Chemistry, 56 (1):99 105 
Galmessa, U., Raina, V. S., Mohanty, T. K. and Gupta, A. K. 2003. Seminal attributes related to age and scrotal circumference in diary bulls. Indian Journal of Dairy Science, 56:376-379.

Gerencser, Z. S., Matics. Z. S., Nagy, I and Szendrő, Z. S. 2011. Effect of lighting schedule on production of rabbit does. World Rabbit Science 19:209-216

Ghosh, S. K., Das, A., Bujarbaruah, K. M., Das, A., Dhiman, K. R. and Singh, N. P. 2008. Effect of breed and season on rabbit production under subtropical climate. World Rabbit Science. 16: 29-33.

Goel, G., Makkar, H. P. S., Francis, G., and Becker, K. 2007. Phorbol esters: structure, biological activity, and toxicity in animals. International Journal Toxicology, 26 (4): 279-288

Gupta, A. K. and Mohanty, T. K. 2003. Testicular biometry and semen quality in Karan Fries bulls. Indian Journal of Diary Science. 56:317319

Hammarneh, A. I., Heeres, H. J., Broekhuis, A. A. and Picchioni, F. 2012. Extraction of Jatropha curcas proteins and application in polyketone-based wood adhesives. International Journal of Adhesion and Adhesives, 30:615625.

Hotz, C. and Gibson, R. S. 2007. Traditional food processing and preparation practice to enhance the bio - availability of micronutrient in plant based diets. Journal of Nutrition, 134 (40):77-100

JMP $^{\circledR}$ SAS 2013 Version 10. SAS institute Incorporated, Cary, NC

Lazzaroni, C., Biagini, D., Redaelli, V. and Luzi, F. 2012. Technical Note: Year, season, and parity effect on weaning performance of the Carmagnola Grey Rabbit breed. World Rabbit Science. 20: 57-60.

Makkar, H. P. S., Kumar, V., Becker, K. 2012. Use of detoxified Jatropha as kernel meal and protein isolate in diets of farm animals. Chapter 21. In, Makker, H.P.S. Biofuel coproducts as livestock feed opportunities and challenges, FAO

Makkar, H. P. S., Aderibigbe, A. O. and Becker, K. 1998. Comparative evaluation of non-toxic and toxic varieties of Jatropha curcas for chemical composition, digestibility, protein degradability and toxic factors. Food Chemistry. 62: $207-215$.

Makkar, H. P. S. and Becker, K. 1999. Plant toxins and detoxification methods to improve feed quality of Tropical Seeds Quality of Tropical Seeds. Asian-Australian Journal Animal Science. 12 (3):467-480

Makkar, H. P. S., Aderibigbe, P. S. and Becker, K. 1997. Potential of Jatropha curcas seed meal as a Protein supplement to livestock feed, constraints to its utilization and possible strategies to overcome constraints to its utilization. Proceedings of the International Symposium on Biofuels and Industrial Products from Jatropha curcas and other. Tropical Oil Seed Plants, Managua, Nicaragua, Mexico, 23-27.

Morton, D. 2006. The use of rabbits in male reproductive toxicology. Environmental Health Perspective. 77, 5-9

Odeyinka, S. M., Oyedele, O. J., Adeleke, T. O. and Odedire, J. A. 2008. Reproductive performance of rabbits fed Moringa oleifera as a replacement for Centrosema pubescens. $9^{\text {th }}$ World Rabbit 
Congress Verona-Italy, June 10-13, pp. 411-416

Ogbu, N. N., Ogbu, C. C. and Okorie, A. U. 2015. Growth performance of broiler chickens fed raw and processed pigeon pea (Cajanus cajan) Seed Meal. Journal Animal Science Advances, 5(7): 13501356

Ogbuewu, I. P. 2008. Physiological responses of rabbits fed graded levels of neem (azadirachta indica) leaf meal. M.sc thesis submitted to Department of Animal Reproductive Physiology Federal University of Technology Owarri. Pp 34

Olomu, J. M., Bamiko, M. A. and Olomu, E. B. 2019. Rabbit Production and Nutrition, a Jachem Publication Pp 115

Oyeyemi, M. O. and Oke, A., Olusola, C., Ajala, O., Oluwatoyin, $O$. and Idehen, C.O. 2002. Differences in testicular parameters and morphological characteristics of spermatozoa as related to age of West African Dwarf bucks. Tropical Journal of Animal Science, 5(1); 99-107

Oyeyemi, M. O. and Okediran, B. S. 2007. Testicular parameters and sperm morphology of chinchilla rabbits fed with different planes of soybean meal. International Journal Morphology 25(1):139144.

Owen, O. J., Amakiri, A. O. and Ezeano, C. I. 2010. The cost benefit analysis of incorporating bitter leaf (Vernonia amygdalina) meal in broiler finisher diet. Proceeding $35^{\text {th }}$ Annual Conference Nigerian Society for Animal Production (NSAP). March 14-17th IbadanNigeria p. 670-674

Pauzenga, U. 1985. Feeding parent stock. Zootecnia international Pp 22- 25
Perry, G. and Petterson, D. 2001. Determining reproductive fertility in herd bulls. University of Missouri Agriculture publication. 2011:1-8

Ross, P. R., Morgan, S. and Hill, C. 2002. Preservation and fermentation: past, present and future. International Journal of Food Microbiology.79:3-16

Togun, V.A. and Egbunike, G.N. 2006. Seasonal variations in the sperm production characteristics of Zebu (white Fulani) cattle genitalia in the humid tropical environment. Middle-East Journal of Science Research 4 (1): 45-51

Wafar, R.J., Tarimbuka, L. I., Sini, T and Adi, Z.A. 2019. Evaluation of fermented sorrel (Hibiscus sabdariffa 1.) seed meal on growth performance and carcass characteristics of weaner rabbits. FUDMA Journal of Agriculture and Agricultural Technology, 5(1): 9-17

Wafar, R.J and Tarimbuka, L.I. 2016. Effect of Substituting Groundnut cake with water spinach (Ipomoea aquatica) Leaf Meal on Performance, Carcass Yield and Blood Profile of Weaner rabbits. FUW Trends in Science and Technology Journal (FSTJ). Vol. 1 (1). Pp 238-242

Wafar, R.J., Yakubu, B and Lalabe, B.C 2017. Effect of Feeding Raw Kapok (Ceiba pentandra) Seed Meal on the Growth Performance, Nutrient Digestibility, Carcass and Organ Weights of Weaner Rabbits. Asian Research Journal of Agriculture 5(3): 1-8

Wafar, R.J. 2013. Effects of replacing toasted sorrel seed (Hibiscus Sabdariffa) meal for soybean meal in broiler finisher diet. Journal of 


\section{Growth and reproductive performance of rabbit bucks}

Animal Production Advances, 3(8): 247-253

Weaver, C.M. and Kanna, S. 2002. Phytate and mineral bioavailability In: Reddy, N.R. and Sathe, S.K., editors Food Phytates. CRC press, Boca Raton., Florida, USA 211224

Yakubu, B and Wafar, R.J. 2014. Effects of processing methods of Leptadenia hastata on growth performance, nutrient digestibility and carcass characteristics of weaner rabbits. IOSR Journal of Agriculture and Veterinary Science. 7 (1) 53-58
Yakubu, B., Aliyara, Y. H., Antyev, M. and Mbahi, T. F. 2017. Effects of fermented Jatropha (Jatropha curcas) seed meal on growth performance, carcass and internal organs evaluation of broiler finisher chickens. Greener Journal of Animal Breeding and Genetics, 3(1):001-008

Zemjanis, R. 1970. Collection and evaluation of semen.In: Diagnostic and therapeutic techniques in animal reproduction. $2^{\text {nd }}$ Edition, Williams and Wilkins Co. Baltimore MD.139-156.

Received: $10^{\text {th }}$ September, 2020 Accepted: $28^{\text {th }}$ January, 2021 